\title{
The City Mouse
}

\section{S. P. Jordon, Saskatoon}

I am a city mouse and I write this story particularly for the benifit of the city dwellers. Possibly such experiences as I will describe will be more wonderful. because of their uncommonness with city folk and I suspect that if they had shared them with me they would feel, as have I, like the city mouse who rarely visits the country and on such occasions always marvels at the interesting animals and birdshe sees there. Won't you join me then $\mathrm{O}$ city dwellers would it be but possible to put the enjoyable hours of a spring and summer into seven hundred words while I relive the past three months of nature's gifts.

The ducks and crows greeted me on my first working morning. The crows had nested in a clump of trees by our machine shed the ducks in A nearby slough. The crows raised a heal thy family of four within five yards of where we daily ate our lunch. The young became so conditioned to our presence that I managed to stroke the head of a young bird which had just learned to fly. The crows often visited the slough. The Red-wings and the ducks made their characteristic fuss. The ducks disappeared. The water receded. About the middle of June I found the corpse of a Blue Winged Teal in some summerfallow that neighbored the slough. Tragedy true - man caused, animal caused, who's to say, who's to know, who's to interfere?

What a wonderfull thrill it was for me to see a large procupine comfortably stationed in the crotch of a dead poplar tree. I stood glowing with delight, and watched him for a full five minutes. So fearless was he that he periodically blinked his eyes as if fighting sleep.

How much more satisfying for me to halt the tractor and capture a young Hungarian Partridge who lagged behind the rest, remove the hard packed clay from his rubbed raw toes, release him and watch him run like his brothers and sisters, than to watch him drop from the sky with lead in his heart.

I really believe that nature lovers and sportsman alike would be amazed at the number of animals and birds that either die or are painfully mained by autornobiles. One solution would be slower speeds. I counted 15 gopher corpses on a highway turn. On a 3 inile stretch between Kegina and Sask- atoon I counted 2 owls, I partridge, 1 meadowlark, 1 dead and 1 wounded Prairie Chicken, l long-tailed weasel and 3 rabbits. Multiply this by a few thousand and there will be some idea attained as to the amount of destruction which occurs on the paved prairie high ways.

Who has ever been attacked by a week old Jack Rabbit? A little one I brought home certainly threw itself at my arm everytime I put it in his box. The fur on his back stood up and while his was not of fear. My wife seemed to know how torhandle him for after being fed with an eye-dropper he curled up in her arms and went to sleep

What a challenge it was to find a shrew and then to atempt to identify it as a Cineveau or a Pigmy shrew, North America's smallest mammal. The teeth alone seemed to be the only possible and positive guide and after an hour long study, aided by a niagnifying glass, I identified my specimen, (equipped with viscious looking den tures) as the Cineveus or Common Shrew.

A 20 mile motor-pile on Last Mountain Lake enabled me to see. a great variety of bird life, while-winged Scoters, Pelicans, California Gulls, Terns, Grebes and Franlkin Gulls were common. Little Arm River abounded with hundreds of ducks. The rise in the water he made this a perfect breeding ground. Two Great Herons graced the air with the approached of our boat, Muskrats splashed, Hawks soared. On a land trip Jack Rabbits bounded away at our approach. Four deer, two majestic bucks and a beautiful doe and her fawn literally sailed over the rolling prairie when we flushed them from a coulee. Some ime later the big $V$ of the doe's ears revealed her presence as she stood in a clover field. Truly a natural ist's. $p$ aradise.

Who has swayed with the wind atop a 30 foot poplar to seek out the occupant of a Red-tailed Hawk's nest. How worth while it was to find a fuzzy white defiant ball of beak, claws and feathers there to meet you at the rim. To be strangely not bothered by the parents that day but to be swooped at with screaming wings a week later when innocently passing by the nest.

So now the crows and the summer have gone. The leaves are leaving the blue. Gone but never frogotton. 